\title{
Disaster Management Practice Towards Diverse Vulnerable Groups in Yogyakarta
}

\author{
Dyah Rahmawati Hizbaron \\ Enviromental Geography Departement, Faculty of Geography, \\ Universitas Gadjah Mada \\ Yogyakarta, Indonesia \\ Corresponding email:dyah.hizbaron@ugm.ac.id \\ Maulida Iffani \\ Enviromental Geography Departement, Faculty of Geography, \\ Universitas Gadjah Mada \\ Yogyakarta, Indonesia \\ Helvetia Wijayanti \\ Enviromental Geography Departement, Faculty of Geography, \\ Universitas Gadjah Mada \\ Yogyakarta, Indonesia \\ Ghalih Nur W. \\ Environmental Geography Departement, Faculty of Geography, \\ Universitas Gadjah Mada \\ Yogyakarta, Indonesia
}

\begin{abstract}
A paradigm shift in disaster management practices have been outlined in the Hyogo Framework for Action and Sendai Framework for Action. The research aims at exploring possible relationship between disaster management programs for vulnerable groups in Daerah Istimewa Yogyakarta Province. This research area randomly selected several hamlets, i.e. Kepuharjo and Umbulharjo Villages, as hazard-prone areas of Merapi volcano eruption; Kricak Kidul and Pingit Villages, as flood hazard-prone areas; and Parangtritis Village as tsunami hazardprone areas. Thereby, the research employs a qualitative approach to describe the relationship amongst two main variables, such as disaster management program (pre, per and post-disaster) either in urban and rural areas especially for vulnerable groups. The results showed that: 1) there are different organization systems in disaster management praxis; 2) the main stakeholder within disaster management praxis is enormous, however BPBD and Social Agency hold a significant role; 3) the main idea of the programs normally focus within emergency situation, yet contemplate the logic into daily business; 3) the distribution and intensity of disaster management praxis yet spatially equal; 4) the output of the program is generally acknowledged to strengthen resilience, however not ensuring sustainability yet. In general, these two agencies have the same objective to establish a disaster resilient community. BPBD was establishing Desa Tangguh Bencana (Destana) with indicators of independence of the village in conducting disaster mitigation activities. Social Agency was forming Kampung Siaga Bencana (KSB) with regard to the sustainability of disaster mitigation activities through monitoring. Meanwhile, the main factors contributing to vulnerability are 1) lack of preparedness; 2) minimum infrastructure support; 3) disaster management system which has not been implemented yet at research area.
\end{abstract}

Keywords-Vulnerability, mitigation, disaster, DI Yogyakarta, Indonesia

\section{INTRODUCTION}

The study observed at various types of disaster management practices that seek to alleviate the problems of vulnerable groups in the Province of Yogyakarta (DIY). Characteristics of vulnerable groups in DIY can be seen from several contributory factors. First, the physical condition of the region as well as its combination of development planning, indicate increased potential risks in DIY. DIY is one of the disaster-prone areas, ranked with a score of 165 (high category) at $14^{\text {th }}$ highest score across Indonesia, according to the study of Indonesian Disaster Risk Index (BNPB, 2014). 


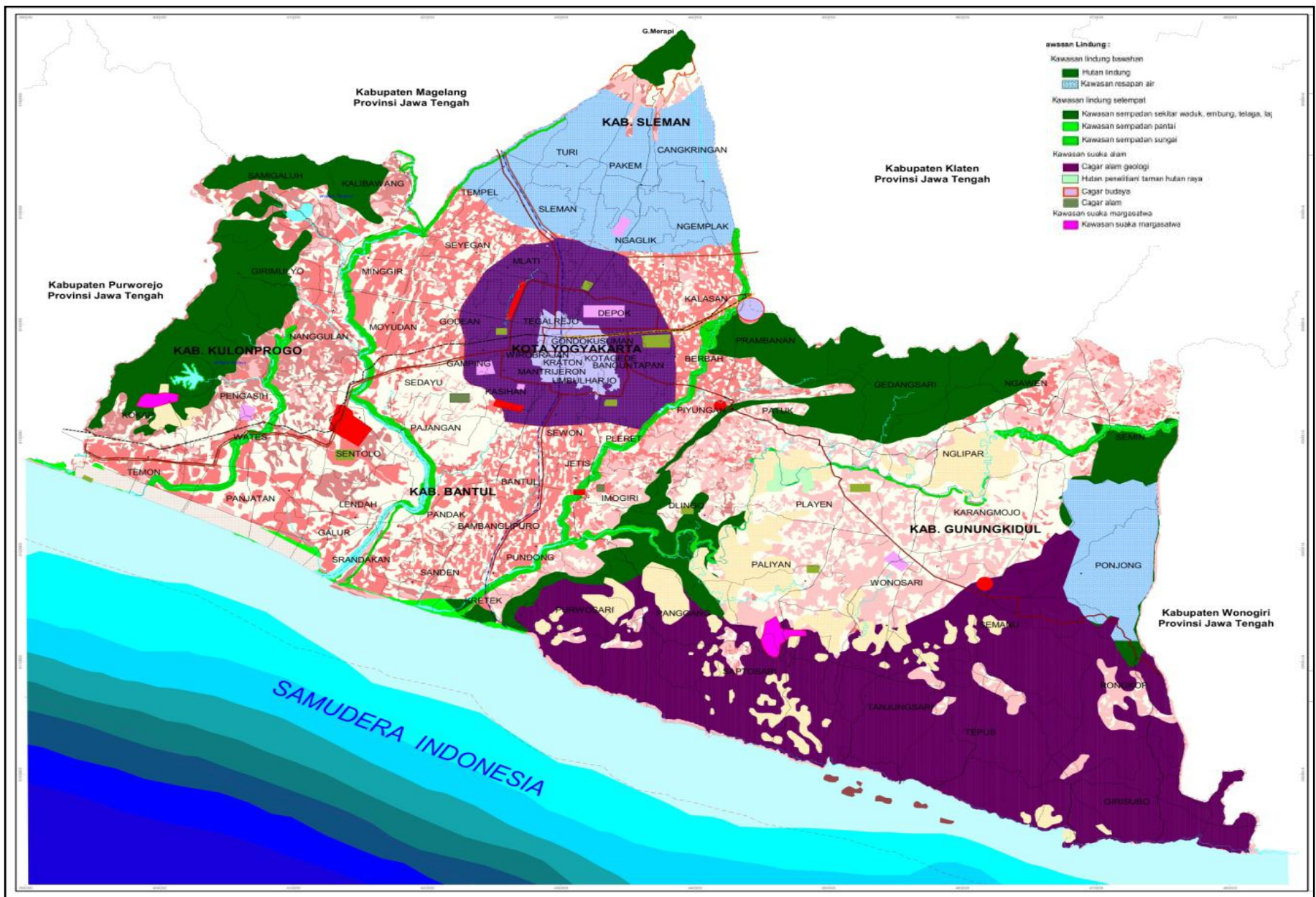

Fig. 1. Map of DIY Spatial 2012-2017 (the image is not scaled)

Furthermore, Yogyakarta had recorded from year 2012 to 2015 at least 656 incidences of high winds, 382 incidences of landslides, 85 floods, 27 earthquakes and 3 incidences of droughts. The conditions would result in vulnerable groups residing in hazard-prone locations. They would get higher potential risks compared to vulnerable groups residing in less hazardous locations.

Second, social and economic characteristics of cantonal vulnerable groups are characterized by its poverty rate and distributed gap of poverty depth. BPS data (2015) on population growth in DIY has recorded increasing inhabitants from $3,393,003$ in 2008 to $3,594,854$ people in 2013 . The population growth is one indication of the potential increase in vulnerability of communities to natural disasters. Further observation showed that the poverty line in DIY increased as inflation in economy, that is from IDR 220,830 per capita/month in March 2009, to IDR 321,056 per capita /month in September 2014. The high urbanization seems to be one of the obstacles in controlling the number of the poor in the urban areas given the lack of decline in the number of poor people in urban areas since 2009 is $14,25 \%$. In short, vulnerable groups resided in urbanized area, provide specified characteristics to those resided in peri-urban area as well as in rural area.
Source: Indonesian Disaster Risk Index (BNPB, 2014)

Third, vulnerable groups are associated with the implementation of disaster management practices. Postearthquake disaster 2006, Yogyakarta had a fairly good social capital to accommodate the potential for disaster, i.e. one with many disaster management practices. Post-volcanic eruption 2010, Yogyakarta had very rapid response due to many stakeholders involvement. Thereby, social capital not only rooted from internal communities, however it also embraced the external stakeholders into the at risk communities. Diverse disaster management practices exemplify on continuous process at community level. Therefore such practices promptly influence their vulnerability. Disaster management practices are often defined as all disaster relief efforts, especially in the emergency response phase and included the stages of predisaster (preparedness and mitigation) as well as post-disaster phase (rehabilitation and reconstruction) (Undang-Undang Republik Indonesia No. 24/2007). This argument underlined the idea that each phase shall contribute to community vulnerability.

Based upon these three main categories of vulnerable groups in Yogyakarta, hence the study aims to identify the characteristics of vulnerable groups linked to the implementation of disaster management practices. The study is divided into three main objectives, as follows: 
- To identify disaster management practices implemented in Yogyakarta

- To identify the causes of vulnerability due to natural hazards in Yogyakarta

- To assess the connection or relationship between the implementation of disaster management practices with the type of vulnerability.

- The concept of disaster management in the world has undergone a paradigm shift that is very dynamic. Some of the paradigm shift outlined in the Hyogo Framework for Action (UNISDR, 2005) and Sendai Framework for Action (United Nations, 2015), namely:

1) Reactive to Responsive Disaster Risk Reduction

2) Emergency to Disaster Risk Reduction

3) Government to Society (Government Based to Community-Based Disaster Risk Reduction)

4) Technical Engineering to Social Engineering (Engineering based to People-centered Disaster Risk Reduction)

The following figure depicts historical recap of disaster management policies in Indonesia (Fig. 2).

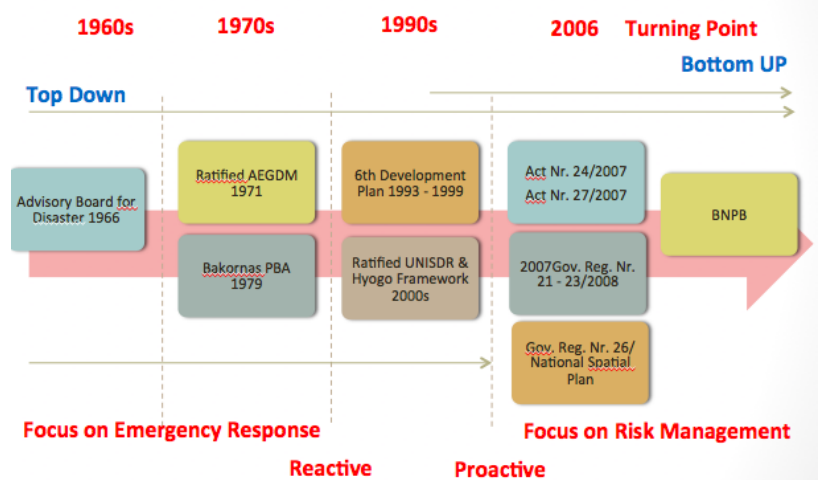

Fig. 2. Shifting Paradigm of Disaster Management Indonesia

Source: Analyse Result, 2016

The shifting turning point was occurred at 2007 whereas Indonesian law on disaster management was first publicly announced. The disaster management praxis in Indonesia was no longer put attention to one phase orientation, which was emergency phase. It has shifted into three phases orientation, such as pre-disaster, per disaster or emergency and postdisaster. The whole cycle of disaster management was considerably one package of disaster relief praxis. Risk analysis often claimed within pre-disaster phase, together with hazard analysis and vulnerability analysis. The importance of doing such analyses mainly to predict accurate scenarios of potential occurrence based upon previous trends and likelihoods.

Research with the theme of vulnerability in disaster-prone areas in the province had been carried out intensively. Hizbaron et al., (2011) has conducted a vulnerability analysis using spatial and temporal approach in disaster-prone areas of the earthquake as one of the key inputs in the preparation of the spatial plan. Related research conducted vulnerability in drought-prone region, Gunung Kidul involving participatory approaches (Khasanah, Hanum, \& Hizbaron, 2014). Furthermore, Hizbaron et al., (2015) highlighted vulnerability analysis using a multi-criteria approach due to lahar flood along the slopes of Merapi Volcano. Definition of vulnerability in this study is emphasized as a measurability of the potential loss, damage and potential loss of natural hazards (Cutter, 1996; Cardona, 2003; UNISDR, 2004; Moser, 2010; Hizbaron et al., 2012; Hizbaron et al, 2015). In general, the vulnerability exploited in this study is not only limited to a condition to be affected, but rather understood as a process that results in a person who is not able to withstand the disruption of certain natural hazards due to limited social capital, physical capital, environmental capital, economic capital and political capital as contained in the theory of livelihood (Ma'Arif \& Hizbaron, 2015; Birkmann \& Teichman, 2010; Rijanta, Hizbaron, \& Baiquni, 2014). The following fig. 3 depicts the research rationale.

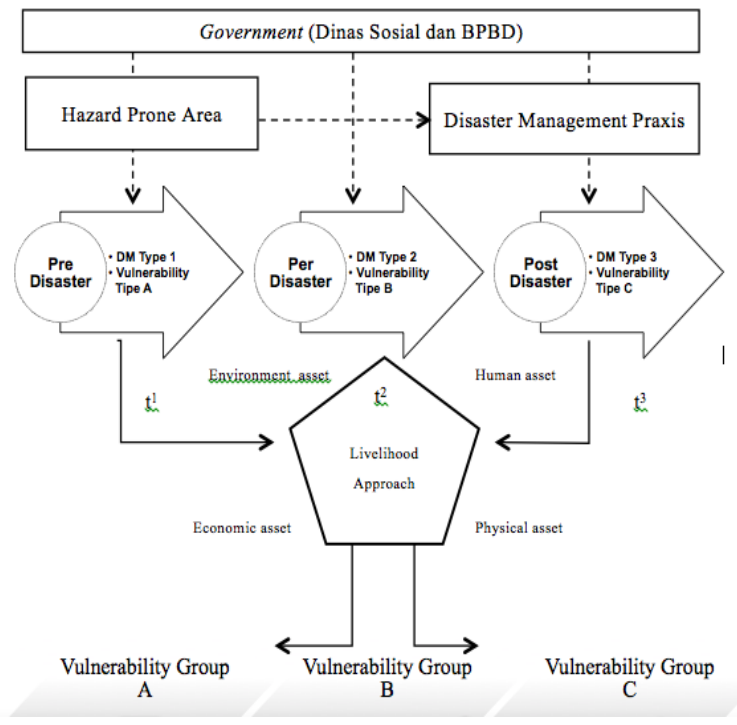

Fig. 3. Research Rationale

The research hence argued, that type of vulnerabilities arise in DIY affected by absences of one factor or more, especially those factors stated within livelihood approach.

\section{METHOD}

This study is a qualitative research that applied the pragmatic approach to disaster relief practices reviewed influence and impact on the formation of a vulnerable group. Research Unit is a district/city, where each district/city is expected to process records that indicate implementation of the practice of disaster relief. Data collection was done through the mechanism of in depth interview towards key figures in each hazard-prone area in DIY. 
TABLE 1. RESEARCH FRAMEWORK

\begin{tabular}{|c|c|c|}
\hline Preparedness & Emergency Response & Rehab-Recons \\
\hline $\begin{array}{l}\text { - Preparation and } \\
\text { testing of } \\
\text { emergency disaster } \\
\text { management plans } \\
\text { - Organizing, } \\
\text { installation and test } \\
\text { of the early warning } \\
\text { system } \\
\text { - Provision and } \\
\text { preparation supplies } \\
\text { to fulfill the basic } \\
\text { needs } \\
\text { - Organizing, } \\
\text { counseling, training, } \\
\text { and simulated } \\
\text { emergency response } \\
\text { mechanism } \\
\text { Evacuation of site } \\
\text { preparation } \\
\text { Preparation of } \\
\text { accurate data, } \\
\text { information, and } \\
\text { updating operating } \\
\text { procedures for } \\
\text { emergency response } \\
\text { Supply and } \\
\text { preparation of } \\
\text { materials, goods, } \\
\text { and tools for the } \\
\text { fulfillment of the } \\
\text { restoration of } \\
\text { infrastructure and } \\
\text { facilities }\end{array}$ & $\begin{array}{l}\text { - Quick and accurate } \\
\text { assessment of the } \\
\text { site, damage, loss, } \\
\text { and resources } \\
\text { - Determination of } \\
\text { disaster emergency } \\
\text { status } \\
\text { - Rescue and } \\
\text { evacuation of } \\
\text { people affected } \\
\text { - Fulfillment of the } \\
\text { basic needs } \\
\text { - Protection of } \\
\text { vulnerable groups, } \\
\text { and } \\
\text { - Restoration of vital } \\
\text { infrastructure and } \\
\text { facilities soon }\end{array}$ & $\begin{array}{l}\text { - Rehabilitations } \\
\text { - Reconstructions } \\
\text { - Rebuilding } \\
\text { infrastructure and } \\
\text { facilities } \\
\text { - Social } \\
\text { reconstructions } \\
\text { - Revival of socio- } \\
\text { cultural life of } \\
\text { society } \\
\text { - Application of } \\
\text { appropriate building } \\
\text { design and use of } \\
\text { better equipment } \\
\text { and resistant to } \\
\text { disasters } \\
\text { - Participation and } \\
\text { involvement of civil } \\
\text { society institutions } \\
\text { and organizations } \\
\text { - Improvement of } \\
\text { socio-economic and } \\
\text { cultural conditions } \\
\text { - Improvement of } \\
\text { public services } \\
\text { - Main improvement } \\
\text { of services in the } \\
\text { community }\end{array}$ \\
\hline
\end{tabular}

\section{FINDING AND DISCUSSION}

\section{A. Study of Vulnerability and Disaster Relief in Kepuharjo and Umbulharjo}

Kepuharjo village and Umbulharjo village are located within a radius of 10 kilometers from the peak of Merapi Volcano. Regions within this radius has the potential danger of a burst of lava (incandescent) > 2 millimeters. Kepuharjo village and the Umbulharjo village are included in disasterprone areas III. The physical condition of the Village Kepuharjo and Umbulharjo village area are traversed by the river that borders the east part of Gendol Glagaharjo village. Gendol River was directly affected by the path of Merapi Volcano eruption in 2010 ago. Vulnerability in Kepuharjo and Umbulharjo villages are strongly influenced by the location of the village near the source of danger. The sufficient condition of the society can be seen from the base of ownership of assets, such as housing, vehicles and even productive land.

Endeavored with such physical assets, consequently put Kepuharjo Village Government to work with multiple agencies and volunteers, such as SKSB, Palem, Board Chakra, and Balerante Community. The local government needs to ensure their optimum efforts to reduce risk potentials. Relations between the two villages exhibit a very strong sense of social capital. Herewith, the local communities-at-risk, sensitively acknowledged symptoms of an eruption. Their sensitivity to smell of burning sulfur constantly increased, very rapid heat improvement, continuous explosive-sound-like during daily activities, and very rapid dry skin, were several indication they have to describe increase potential of volcanic eruption risk. Herewith their human capital was more than enough to minimize their vulnerability. In addition to that, the local community-at-risks provide a strong kinship with their relatives, which off course very much important to develop their mutual information mechanism. Local communities are able to circulate information via "gethok tular" which mainly focus to distribute information instantly. Figure 8 describes the type of vulnerability that is formed on stage before, during and after a disaster.

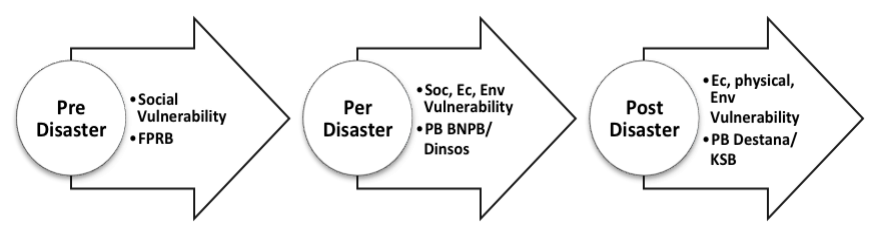

Fig. 4. Vulnerability Type 1 of Kepuharjo Village and Umbulharjo Village

The fig. 4. indicated the types of vulnerability according to disaster management praxis for the area. Local communities at Kepuharjo village were guided by BPBD to form Forum Pengurangan Risiko Bencana (FPRB) or Forum of Disaster Risk Reduction in 2014. The FPRB chaired by the local administrative chief, and had approximately 40 members consisted of community leaders, youth, and LPMD. The forum became the most important foundation to form Desa Tanggap Bencana (Destana) or Resilient Village. The first task of FPRB was to make vulnerability maps displayed at the area, with the help of the local communities. The data collected was then made as spatial data by BPBD and provided a map of vulnerability for the area. The village also serves as one of the pilot project from Social Agency to form as Preparedness Hamlet or Kampung Siaga Bencana which had been declared since 2006
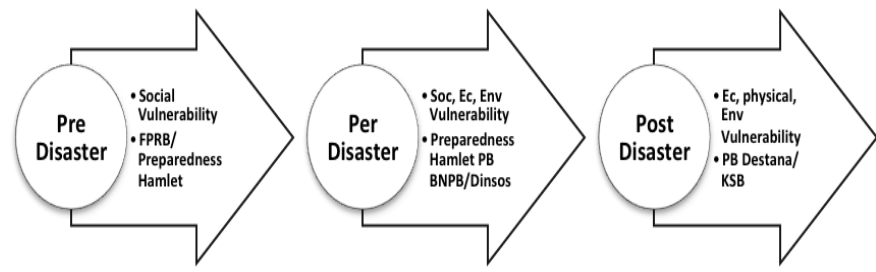

Fig. 5. Vulnerability Type 1 of Pakem Sub-District

The research tries to observe the larger framework via subdistrict observation. As the vulnerability type 1 highlights that existence of a program called "Destana" not necessarily lower the vulnerability level of a community. During each phase, the types of vulnerability may exist concomitantly. Parallel to that, the existence of "Destana" increases the community capacity to deal with disaster occurrence, therefore the vulnerability level yet defined by the existence of the program.

To add, Destana of Kepuharjo has made contingency plans for volcanic eruption disaster. The contingency plans are used as a guide to implement emergency response practices. These guidelines apply only to deal with volcanic eruptions. The contingency plan guide is divided into two types based upon tis hazard types, such as effusive and explosive eruptions. Evacuation operation is set within the contingency plan. 
Evacuation is done for vulnerable groups (infants, toddlers, pregnant women, disabled, and elderly), ordinary citizens, and cattle. Cattle become one of the priorities of evacuation because most people do not want to be evacuated if their livestock are not saved. The community owns their private vehicles such as cars to evacuate themselves, but the one of the obstacles that may occur is a traffic jam because of the huge number of cars used to flee. Before the disaster, the headman of the village carried out the main responsibility of evacuation activity. Recently, nearly all communities-at-risk in the research area, receive the same responsibility, have similar roles within the scenario of evacuation and fully aware of where to go, due to existence of contingency plan.

As noted earlier, at this research area also receive another program entitled as Kampung Siaga Bencana or Preparedness Hamlet from Social Agency. In addition to the program, Kepuharjo and Umbulharjo villages jointly signed $\mathrm{MoU}$ (Memorandum of Understanding) with the village of Wukirsari to form a Sister Village. Sister Village is a cooperation system to conduct emergency responses to volcanic eruptions. Wukirsari village acts as a buffer villages and refugee camps for Kepuharjo and Umbulharjo villages. Such disaster management praxis contribute to very rapid disaster management activities especially within the emergency situation, not yet highlights the pre and per disaster activities.

\section{B. Vulnerability Assessment and Disaster Mitigation in Yogyakarta}

BPBD (Badan Penanggulangan Bencana Daerah/Regional Disaster Management Agency) of Yogyakarta has pronounced that Winongo River has a high risk of flood to people, according to the information from the Coordinator of Evacuation in Desa Tanggap Bencana (Destana). The statement was issued since Kricak Village is located right at the junction between two streams, called Tempuran. Amidst such poor physical capital, the area also suffers from high vulnerability level, due to insecure social economic background. As seen in fig. 6 , this area received minimum programs of disaster risk reduction. Unlike those in Merapi Volcano areas, this citycentred-hazard-prone area considers adequate in providing selfassistance during emergency situation.

Low incomes groups generally promote low quality of housing, with densely populated environment and minimum health services such as poor sanitation. Characterized by low quality of settlement, or even we call it as slum, these communities at risk are not only vulnerable from the social aspect, they also experiences an inability to save private property like houses, valuable assets such as household appliances, vehicles, and so forth (Fig. 6.).
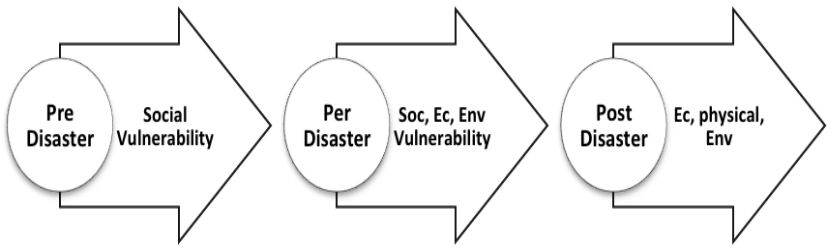

Fig. 6. Vulnerability Type in Kotabaru

Consider the lahar flood as a collateral hazard of volcanic eruption, their risk potential analyzed differently from the eruption itself. Therefore, the importance of the area along channels or streams within Yogyakarta City was not fully taken into consideration for any Disaster Management Praxis. According to the observation, there was Kampung Tanggap Bencana Program (Katana) in Kotabaru which was done by the government in forming resilience in 2014. In the early stages, the team established a structured management to run the program accompanied by BPBD of Yogyakarta. Then they elected a chairman, a coordinator of field evacuation, a logistics coordinator, a coordinator of the shelter, and a coordinator of trauma healing. Board of Katana should report to the SAR (Search and Rescue) Yogyakarta and BPBD Yogyakarta when a disaster strikes. SAR Yogyakarta actively participates in activities to help evacuate the victims. As at the time of the floods, in March 2016, the SAR team conducted an evacuation of two people from the flooded safely.

Implementation of disaster management practices by Katana has a good progress in terms of preparedness of society when the flood occurred. Basically, this change occurred because of an emerging awareness of the private residential location and activity of the community is in direct contact with Winongo riverbanks. The emergence of this awareness is supported by the formation of Katana, which plays an important role in improving community preparedness to disasters, especially floods, but coupled with the knowledge on preparedness to natural disasters such as landslides, and social disasters such as crimes in general.

Unlike the experience of Katana, the process of Kampung Siaga Bencana (KSB) or Preparedness Hamlets provides different shades. This process is closely related to participatory mechanisms. Although it has been going on for two years, the KSB Pengok program continues to make improvements and evaluation. One of them is in terms of routine activities of society, such as simulation and socialization activities. However, in general, the Pengok village community experienced a change in attitude in the face of disaster. A big difference in public attitudes was seen when it faced devastating floods in 2010 and 2016. The Boards of KSB are responsible for activities that support knowledge of the communities located in prone areas to disaster alert to the phenomenon, such as monitoring water levels, which help people in flood hazard detect the river code. In addition, the Tagana (Taruna Siaga Bencana) of Yogyakarta has a program to attach posters to teach the community about the early action when disasters occur. This poster will be installed in the hall of RT/RW (neighborhood/hamlet) of the city of Yogyakarta. While for the assistance of medical equipment and medicines will be helped by the Dinas Kesehatan (Public Health Office) Yogyakarta.

\section{Disaster Management Practices and Vulnerable Groups in Tsunami-prone Areas}

Bantul district is adjacent directly to the Indian Ocean and has a long coastline up to 17 kilometers (Pemerintah Kabupaten Bantul, 2012). There are at least three districts with 11 coastal villages directly adjacent to the Indian Ocean. These districts are Kretek District, Sanden and Srandakan. Determination of vulnerable groups by FPRB in Desa Parangtritis performed by the physical condition of the person in responding the 
emergency. Due to its physical capital, the area is likely exacerbate by Tsunami.

The social capital in this area responded rather differently than those in Sleman and Yogyakarta. Vulnerable groups in this respect are those that are less or even unable to save themselves or conduct emergency responses when a disaster occurs. They are elderly, children under five year- old, pregnant women, and people who have a disability or disabled. Unfortunately, the most important access for evacuation generally yet ready to conduct evacuation. Social and economic factors are prior, since most of them heavily engaged to physical capital as their main source of living. Not so much alternative, they can do to obtain monthly income, therefore their vulnerability are quite specific compare to other case studies.

Parangtritis village has a disaster management practices initiated by BPBD of Yogyakarta through BPBD of Bantul. Destana (Desa Tangguh Bencana/ Disaster Resilient Village) Parangtritis was initiated by BPBD as disaster risk reduction efforts. BPBD see tsunami as a disaster that must be solved and has a high risk, so they proposed a formation of FPRB (Forum Pengurangan Risiko Bencana/ Disaster Risk Reduction Forum) in the area. Destana of Parangtritis was formed in 2011 that was ratified by the headman of Parangtritis, society, and the BPBD of Bantul. Hazards concerned by Destana of Parangtritis are tsunamis, floods, and landslides. Public participation in making emergency response scenarios is quite good, because the community participated in determining the temporary evacuation, final evacuation, evacuation routes and other scenarios. An increased sensitivity about the disaster phenomenon has been shown in the community.

\section{CONCLUSION AND SUGGESTIONS}

The paradigm of disaster management practices that are carried out in Yogyakarta has been responsive, although not completely. There are still many things that need to be improved to increase community participation. Disaster Risk Reduction phase has been applied even though the main focus is still centered on Emergency Response. Technical and social modification have been applied in all three study areas. The social modification are attempted in various forms of activities such as Destana/KSB and Katana.

The results showed that 1) there are differences in the practice of organizing disaster management systems; 2) the main stakeholders in the activities of disaster management practices are BPBD and Social Agency; 3) the disaster management program is focused on strengthening emergency response phase; 4) the implementation of disaster management program has been carried out in various regions but the intensity has not been evenly distributed; 5) output of disaster management program is a disaster-resilient community, but has not put the sustainability efforts. Furthermore, BPBD formed a Destana (Desa Tangguh Bencana/Disaster Resilient Village) with indicators of independence of the village in conducting disaster mitigation activities. Meanwhile, Social Agency formed a KSB (Kampung Siaga Bencana) with regard the sustainability of the disaster mitigation activities through monitoring. Factors underlying the vulnerability that can be identified are: 1) lack of preparedness of people living in hazard-prone areas; 2) lack of supporting infrastructure in disaster risk reduction management; 3 ) the systematic disaster management in the study area has not been implemented.

\section{REFERENCES}

[1] Birkmann, J., \& Teichman, K. v, (2010), "Integrating disaster risk reduction and climate change adaptation: Key challenges - scales, knowledge and norms," Sutain Sci , 5, 171 - 184, Number footnotes separately in superscripts, Place the actual footnote at the bottom of the column in which it was cited, Do not put footnotes in the reference list, Use letters for table footnotes.

[2] Badan Nasional Penanggulangan Bencana, (2014), "Indeks Risiko Bencana Indonesia Tahun 2013,”Jakarta : BNPB.

[3] Badan Pusat Statistik, (2016), "Jumlah Penduduk Menurut Kabupaten/ Kota di DI," Yogyakarta, Acsessed at yogyakarta.bps.go.id/link/TableStatis/view/id/70, July 4th, 2016

[4] Cutter, Susan L, (1996), "Vulnerability to Environmental Hazard," Progress in Human Geography, Vol. 20, pp 529-539, Desember 1996.

[5] Hizbaron, D., Baiquni, M., Sartohadi, J., \& Rijanta, R, (2012), "Urban Vulnerability in Bantul District, Indonesia - Towards Safer and Sustainable Development," Sustainibility vol 4 DOI:10.3390/su4092022 , 2022-2037.

[6] Hizbaron, D. R., Rahmat, P. N., Setyaningrum, A., \& Malawani, M. N (2015), "Kajian Pola Spasial Kerentanan Sosial, Ekonomi dan Fisik di Wilayah Rawan Bencana Erupsi Gunungapi Merapi, Yogyakarta," Jurnal Riset Kebencanaan Indonesia , 1 (1), 16-24.

[7] Khasanah, A., Hanum, N., \& Hizbaron, D, (2014), "Capacity Improvement Towards Participatory Water Management in Peri-Urban of Giripurwo, Gunungkidul Yogyakarta. In Hartono, S. Purwono, S. Maarif, D. Sofjan, \& Suhadi (Ed.), Proceeding The 6th International Graduate Students and Scholars' Conference in Indonesia Theme: Science, Spirituality and Local Wiscom: Interdisciplinary Approaches to Current Global Issues (pp. 321-331)," Yogyakarta: The Graduate School Universitas Gadjah Mada.

[8] Ma'arif, S., \& Hizbaron, D, (2015), "Strategi Menuju Masyarakat Tangguh Bencana dalam Perspektif Sosial," Yogyakarta, Indonesia: Gadjah Mada University Press.

[9] Moser, S, (2010), "Now more than ever: The need for more societally relevant research on vulnerabilityand adaptation to climate change," Applied Geography, 30(4), 464-474.

[10] O, D, Cardona, (2003), "The Need for Rethinking the Concepts of Vulnerability and Risk from a Holistic Perspective: A Necessary Review and Critism for Effective Risk Management," In G. Bankoff, G. Frerks, and D. Hilhorst, editor, Mapping Vulnerability: Disaster, Development and People, chapter 3. London, 2003.

[11] Pemerintah Kabupaten Bantul, 2012 http://dkp.bantulkab.go.id/filestorage/dokumen/2014/07/Data\%20Kelaut an,\%20Pesisir,\%20dan\%20Pulau-Pulau\%20Keci1\%202013.pdf download $25^{\text {th }}$ August 2016 on 1:28 pm.

[12] Rijanta, R., Hizbaron, D., \& Baiquni, M, (2014), "Modal Sosial dan Manajemen Bencana, ” Yogyakarta, Indonesia: Gadjah Mada University Press.

[13] United Nation , (2015), "Sendai Framework for Disaster Risk Reduction 2015-2030," United Nation. Geneva: United Nation.

[14] Undang-undang Republik Indonesia No. 24/2007 Tentang Penanggulangan Bencana

[15] UNISDR, (2005), “Hyogo Framework for Action 2005-2015, ” World Conference on Disaster Risk Reduction , UNISDR. Kobe: United Nation. 